\title{
Attenuation by glucose of the hyperactivity induced in mice by combined tripelennamine and morphine
}

\author{
MARIO SANSONE, MARIO BATTAGLIA, and FLAMINIA PAVONE \\ Consiglio Nazionale delle Ricerche, Rome, Italy
}

\begin{abstract}
The present study examined the effects of glucose on the hyperactivity induced by morphine $\left(10 \mathrm{mg} / \mathrm{kg}\right.$ ), given alone or combined with the histamine $\mathrm{H}_{1}$-receptor antagonist tripelennamine (2.5 or $5 \mathrm{mg} / \mathrm{kg}$ ), in mice of the CD-1 strain. In the first experiment, glucose $(50,100,250$, or $500 \mathrm{mg} / \mathrm{kg}) \mathrm{had}$ no significant effect on spontaneous locomotor activity, but at the dose of $100 \mathrm{mg} / \mathrm{kg}$ significantly reduced morphine-induced hyperactivity. In the second experiment, the administration of glucose (50 or $100 \mathrm{mg} / \mathrm{kg}$ ) was also able to attenuate the locomotor stimulation induced by combined tripelennamine and morphine. The results are consistent with the hypothesis that glucose may inhibit opiate functions and indicate that glucose may exert an inhibitory action even on the central action of combinations of opiate and antihistaminic agents, drug combinations able to produce additive euphoric effects in humans.
\end{abstract}

Several animal studies have reported interferences by glucose of the effects exerted by various centrally acting drugs in learning and memory (Kopf \& Baratti, 1994, 1996; Stone, Croul, \& Gold, 1988; Stone, Walser, Gold, $\&$ Gold, 1991) as they have in other behavioral tests (Stone, Cottrill, Walker, \& Gold, 1988; Stone, Rudd, \& Gold, 1990). Considerable evidence indicates that glucose interferes with cholinergic mechanisms and with the effects of cholinergic agents (Kopf \& Baratti, 1994, 1996; Pavone, Capone, Battaglia, \& Sansone, 1998; Stone, Cottrill, \& Gold, 1987; Stone, Cottrill, et al., 1988; Stone, Croul, \& Gold, 1988), but interferences by glucose of the opiate mechanisms have also been reported (Stone et al., 1991). In particular, glucose attenuates morphine-induced analgesia (Lux, Brase, \& Dewey, 1988; Simon \& Dewey, 1981) and prevents behavioral effects of the opiate, such as locomotor stimulation (Stone et al., 1990) and impairments of inhibitory avoidance and spontaneous alternation (Ragozzino, Parker, \& Gold, 1992; Stone et al., 1991).

Previous studies have shown that morphine-induced hyperactivity might be enhanced by some antihistaminic drugs, such as tripelennamine and other histamine $\mathrm{H}_{1}$ receptor blockers (Leza, Lizasoain, \& Lorenzo, 1991; Sansone, Castellano, \& D'Amato, 1986; Sansone, D'Udine, Renzi, \& Vetulani, 1987). In the present study, we investigated whether glucose, at doses that reduced the hyperactivity induced by morphine alone, would be able to also attenuate the locomotor stimulation produced by the opiate combined with tripelennamine. Even if less effective than other antihistaminics in enhancing morphineinduced hyperactivity (Sansone et al., 1986; Sansone et al.,

Correspondence should be addressed to F. Pavone, Istituto di Psicobiologia e Psicofarmacologia, Viale Marx 15-43, I-00137 Roma, Italy (e-mail: pavone@kant.irmkant.rm.cnr.it).
1987), tripelennamine was chosen for the present study because experimental research on antihistaminic-opiate combinations had been prompted by reports indicating a considerable abuse by heroin addicts of the narcotic agonist-antagonist pentazocine combined with tripelennamine ("Ts and blues"), in certain areas of the United States (Lahmeyer \& Steingold, 1980; Showalter, 1980). Combination of the two drugs produced additive euphoric effects in human subjects (Jasinski, Johnson, \& Henningfield, 1984).

In the present study, the first experiment confirmed the ability of glucose to reduce morphine-induced hyperactivity in our experimental conditions too. The second experiment demonstrated attenuation by glucose of the locomotor stimulation induced by combined tripelennamine and morphine.

\section{METHOD}

\section{Subjects}

The subjects were naive male mice, $8-9$ weeks old, of the randomly bred CD-1 strain (Charles River, Calco-Como, Italy). Upon their arrival in the laboratory (at least 1 week before the experiment), the mice were housed in standard transparent plastic cages (4 per cage) under standard animal-room conditions: free access to food and water, 12:12-h light:dark cycle (lights on at 7:00 a.m.), ambient temperature of $23^{\circ} \mathrm{C}$. The experiments were carried out between 9:00 a.m. and 1:00 p.m.

Care and handling of the animals were in accordance with NIH ethical regulations. The experimental protocol was approved by the Italian Ministry of Health on November 27, 1995 (Decree 285/95-B).

\section{Apparatus}

Locomotor activity was measured in a computer-controlled apparatus consisting of eight toggle-floor boxes, each divided into two $20 \times 10 \mathrm{~cm}$ compartments connected by a $3 \times 3 \mathrm{~cm}$ opening. For each mouse the number of crossings from one compartment to the other was recorded by means of a microswitch connected to the tilt- 
ing floor of the box. The apparatus was located in a sound-insulated cubicle.

\section{Drugs}

Glucose (D-glucose, anhydrous, Sigma), tripelennamine hydrochloride (Sigma), and morphine hydrochloride (Ghieu), dissolved in distilled water, were injected intraperitoneally in a volume of $10 \mathrm{ml} / \mathrm{kg}$. Control injections (dose 0 of the drugs) consisted of the administration of saline solution $(0.9 \% \mathrm{NaCl})$.

\section{Procedure}

In the first experiment, the animals were injected with glucose $(0$, $50,100,250$, or $500 \mathrm{mg} / \mathrm{kg}$ ) and, $15 \mathrm{~min}$ later, with morphine hydrochloride ( 0 or $10 \mathrm{mg} / \mathrm{kg}$ ). A $30-\mathrm{min}$ activity test started $15 \mathrm{~min}$ after the second injection. Each experimental group included 16 subjects.

In the second experiment, glucose $(0,50$, or $100 \mathrm{mg} / \mathrm{kg})$ and tripelennamine hydrochloride $(0,2.5$, or $5 \mathrm{mg} / \mathrm{kg})$ were given as a mixed solution, in a single injection, $30 \mathrm{~min}$ before testing. Fifteen minutes after the first treatment, the mice received a second injection with morphine hydrochloride ( 0 or $10 \mathrm{mg} / \mathrm{kg}$ ). Groups receiving saline as the second injection (dose 0 of morphine) consisted of 16 subjects; groups receiving morphine consisted of 24 mice.

\section{Statistical Analysis}

The results were analyzed by nonparametric statistical methods. Median number of crossings and semi-interquartile range (Q1-Q3) were calculated for each experimental group. Significance of the differences among the groups receiving the same dose of glucose was evaluated by means of the Kruskal-Wallis one-way analysis of variance (ANOVA); individual between-group comparisons were performed using the Mann-Whitney $U$ test.

\section{RESULTS}

The results of the first experiment, concerning the effects of glucose and morphine, given alone or combined, are reported in Figure 1, as median number of crossings recorded during $30 \mathrm{~min}$, for each experimental group. A Kruskal-Wallis ANOVA indicated a significant difference among the groups $[H(9)=41.67, p<.001]$. Individual between-group comparisons (Mann-Whitney $U$ test) revealed no significant effect $(p s>.05$ ) of the four tested doses of glucose given alone, while morphine alone $(10 \mathrm{mg} / \mathrm{kg})$ significantly $(p<.01)$ increased the number of activity crossings. Glucose, even if ineffective alone, reduced morphine-induced hyperactivity significantly at the dose of $100 \mathrm{mg} / \mathrm{kg}$. In particular, mice receiving morphine following after $100-\mathrm{mg} / \mathrm{kg}$ glucose exhibited a number of activity crossings significantly lower than that of mice treated with morphine alone $(p<.05)$ and not significantly different from that of mice treated with glucose alone $(p>.05)$.

Figure 2 shows the effects on locomotor activity of combined tripelennamine and morphine in the absence of glucose treatment (GLU 0 ) and in mice receiving glucose simultaneously with tripelennamine (GLU 50 and GLU 100). Kruskal-Wallis ANOVAs indicated a significant difference among the groups for each dose of glucose $[H(5)=52.93, p<.001 ; 29.26, p<.001 ;$ and 12.36 , $p<.05$, for glucose 0,50 , and 100 , respectively]. Individual between-group comparisons indicated no significant effect of tripelennamine, administered without mor-

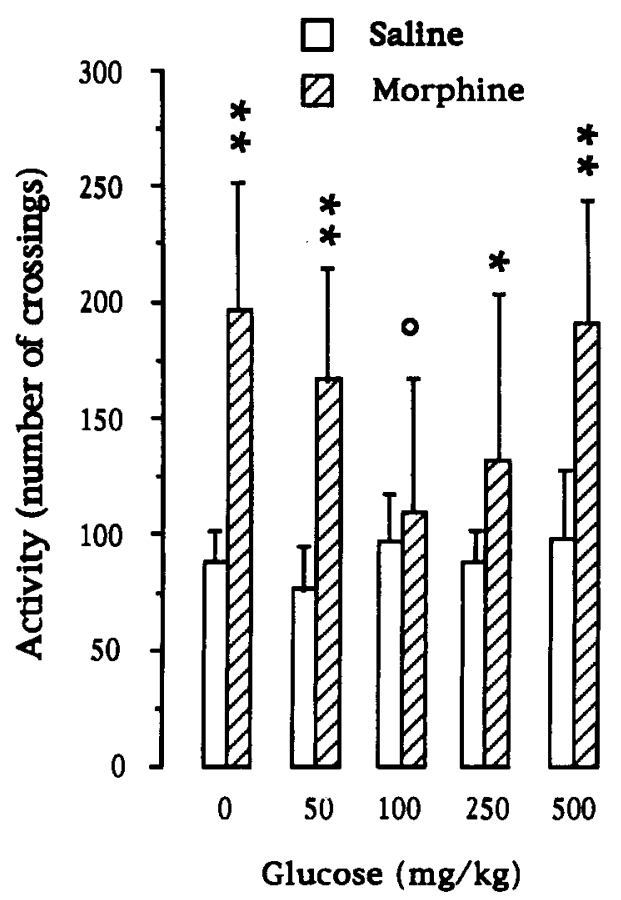

Figure 1. Locomotor activity, measured during $30 \mathrm{~min}$, in mice receiving saline solution or morphine hydrochloride $(10 \mathrm{mg} / \mathrm{kg})$, 15 min after the administration of glucose. The activity test started $15 \mathrm{~min}$ after the second injection. Columns represent median crossings; vertical lines indicate semi-interquartile ranges. Significances by the Mann-Whitney $U$ test: ${ }^{*} p<.05$, ${ }^{*} p<.01$, morphine versus the corresponding saline group, and ${ }^{\circ} p<.05$, versus morphine alone (dose 0 of glucose).

phine, in the absence of glucose as in glucose-treated mice $(p s>.05)$. Morphine alone significantly $(p<.01)$ increased locomotor activity in mice that did not receive glucose. In the absence of glucose, combinations of tripelennamine and morphine increased locomotor activity more than did morphine alone, but such enhancement was not statistically significant ( $p s>.05$ ). Glucose, at the dose of $50 \mathrm{mg} / \mathrm{kg}$, did not change the effect of morphine alone $(p>.05)$ but did prevent the locomotor stimulation induced by morphine combined with $5-\mathrm{mg} / \mathrm{kg}$ tripelennamine $(p<.05)$. At the dose of $100 \mathrm{mg} / \mathrm{kg}$, glucose reduced the hyperactivity induced either by morphine alone $(p<.01)$ or by combined tripelennamine and morphine $(p s<.05)$.

Enhancement of morphine-induced hyperactivity by tripelennamine and the related attenuating action of glucose were more evident, and statistically significant, when the data analysis was applied to the first $15 \mathrm{~min}$ of the 30-min activity test. Median crossings (Mdn; interquartile ranges in parentheses) were calculated for all morphine-treated groups of mice: morphine alone or combined with $2.5-$ and $5-\mathrm{mg} / \mathrm{kg}$ tripelennamine, $\mathrm{Mdn}=$ $101.0(71-122), 127.0(86-157)$, and $122.5(90-137)$, respectively, in the absence of glucose; $\mathrm{Mdn}=89.5$ $(80-123), 105.5(84-130)$, and $80.0(55-145)$, in the presence of $50-\mathrm{mg} / \mathrm{kg}$ glucose; $\mathrm{Mdn}=69.0(48-96), 101.5$ 


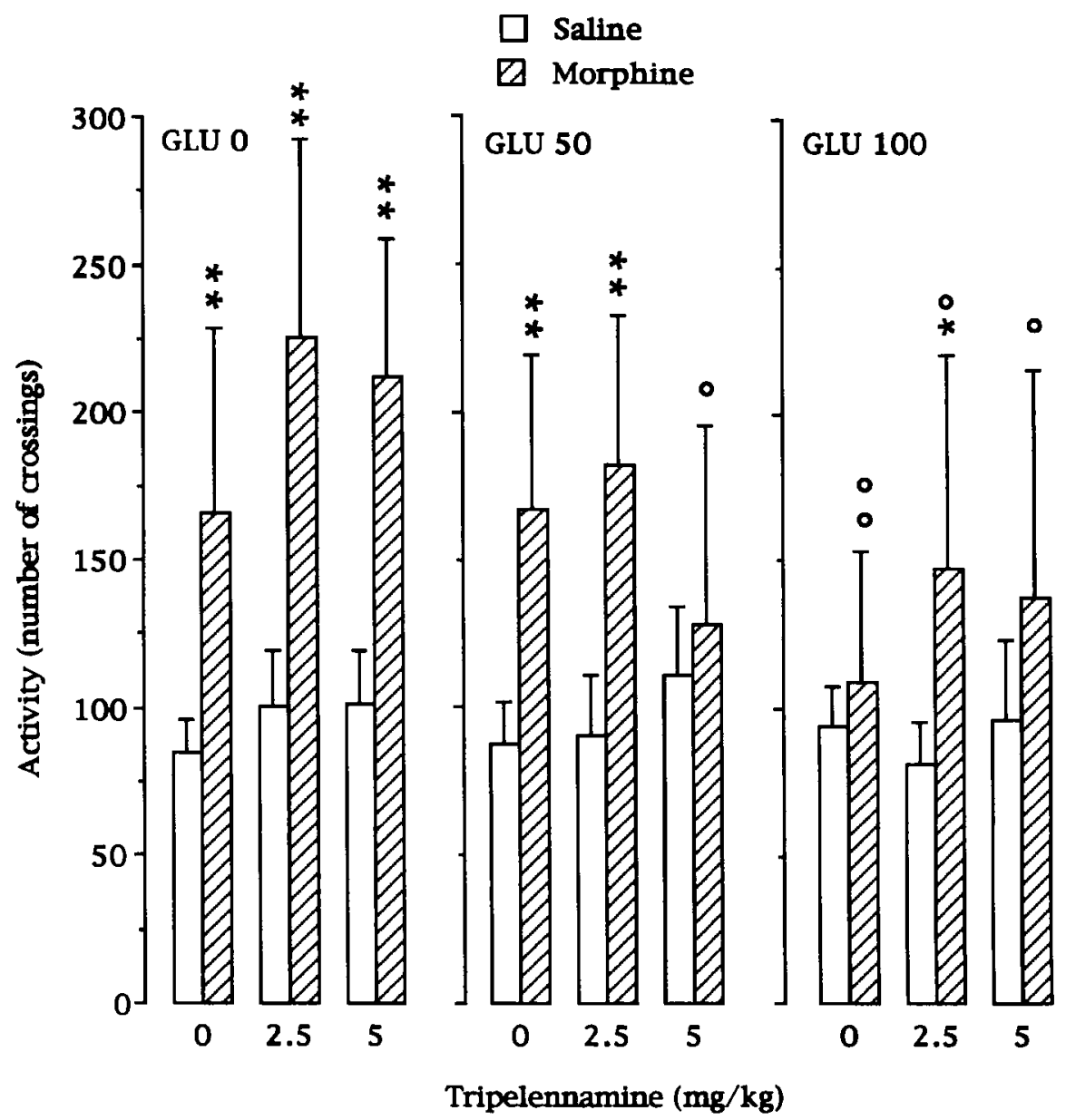

Figure 2. Locomotor activity, measured during $30 \mathrm{~min}$, in mice receiving saline solution or morphine hydrochloride $(10 \mathrm{mg} / \mathrm{kg}) 15 \mathrm{~min}$ after the administration, in a single injection, of glucose (GLU: 0,50 , or $100 \mathrm{mg} / \mathrm{kg}$ ) and tripelennamine hydrochloride. The activity test started 15 min after the second injection. Columns represent median crossings; vertical lines indicate semi-interquartile ranges. Significances by the Mann-Whitney $U$ test: ${ }^{*} p<.05,{ }^{\star \star} p<.01$, morphine versus the corresponding saline group; ${ }^{\circ} p<.05,{ }^{\circ 0} p<.01$, versus GLU 0 , at corresponding doses of tripelennamine and morphine.

(56-121), and $91.0(63-131)$ in the presence of $100-\mathrm{mg} / \mathrm{kg}$ glucose. The Mann-Whitney $U$ test showed that the hyperactivity induced by morphine, in the absence of glucose, was significantly enhanced by both doses of tripelennamine $(p s<.05)$. The effects of glucose were similar to those described for the whole 30 -min activity test. At the dose of $50 \mathrm{mg} / \mathrm{kg}$, glucose significantly reduced the locomotor stimulation induced by morphine combined with $5 \mathrm{mg} / \mathrm{kg}$ tripelennamine $(p<.05)$. At the dose of $100 \mathrm{mg} /$ $\mathrm{kg}$, glucose significantly attenuated the hyperactivity induced either by morphine alone or by combined tripelennamine and morphine $(p s<.05)$.

\section{DISCUSSION}

In agreement with previous findings (Stone et al., 1990), peripheral administration of glucose in the present study did not affect spontaneous locomotor activity in mice but did reduce morphine-induced hyperactivity. Glucose was also able to attenuate the locomotor stimulation produced by morphine combined with the histamine $\mathrm{H}_{1}$-receptor blocker tripelennamine. Combinations of tripelennamine and morphine, as previously reported (Sansone et al., 1986; Sansone et al., 1987), increased locomotor activity more than did morphine alone, the effect being statistically significant during the first half of the $30-\mathrm{min}$ activity test.

The neurochemical mechanisms involved in the central action of glucose are not yet clear, but consistent evidence suggests that glucose administration may augment central cholinergic functions and impair opiate functions (Stone et al., 1991). A cholinergic activation by glucose has been demonstrated by behavioral studies showing that glucose administration attenuates the hyperactivity pro- 
duced by the muscarinic antagonist scopolamine (Stone et al., 1987) and enhances tremors induced by physostigmine, a cholinomimetic agent acting through acetylcholinesterase inhibition (Stone, Cottrill, et al., 1988). An enhancement of the central cholinergic function seems to play an important role even in the improving effects exerted by glucose in learning and memory tasks (Kopf \& Baratti, 1994, 1996; Pavone et al., 1998; Stone, Croul, \& Gold, 1988). The cholinomimetic action of glucose might be due to a facilitation of synthesis and/or release of acetylcholine (Kopf \& Baratti, 1996; Ragozzino, Unick, \& Gold, 1996). On the other hand, an inhibitory action of glucose on central opiate functions has been assumed on the basis of experimental evidence indicating that glucose may antagonize the antinociceptive action of morphine (Lux et al., 1988; Simon \& Dewey, 1981) and may reverse morphine-induced impairments of inhibitory avoidance and spontaneous alternation performance (Ragozzino et al., 1992; Stone et al., 1991). Reduction by hyperglycemia of morphine effects might be due to reduced binding of the drug to opiate receptors (Shook, Kachur, Brase, \& Dewey, 1986), but such a hypothesis, supported by a previous neurochemical investigation (Brase, Han, \& Dewey, 1987), was not confirmed by further experimental findings (Khawaja \& Green, 1992).

Both the inhibition of opiate systems and the enhancement of cholinergic activity may contribute to producing the attenuating action of glucose on morphine-induced hyperactivity (Stone et al., 1990). Since cholinergic activation may be due, at least in part, to opiate inhibition, Stone et al. (1990) suggested that the attenuation of morphine-induced hyperactivity by glucose might be ascribed to a glucose-cholinergic-opiate interaction. It is likely that the same neurochemical mechanisms are involved in the attenuation by glucose of the locomotor stimulation induced by tripelennamine-morphine combinations, but the involvement of other neurotransmitter systems cannot be excluded. In fact, besides their specific $\mathrm{H}_{1}$-receptor-blocking activity, antihistaminics interact with various neurotransmitter systems (Douglas, 1985), so that interactions with the neurotransmitters mediating the behavioral effects of morphine may occur downstream of the opiate receptors (Sansone et al., 1987). However, dopamine, noradrenaline, and particularly serotonin are the neurotransmitters that seem to be mainly involved in the central action of histamine $\mathrm{H}_{1}$ receptor blockers and in their interaction with opiates (San-Martin-Clark, Cuellar, Leza, Lizasoain, \& Lorenzo, 1996; Suzuki, Mori, Tsuji, Misawa, \& Onodera, 1997), but at present no information is available on the effects of peripheral administration of glucose on central monaminergic systems.

In conclusion, the present study demonstrates that peripheral administration of glucose attenuates the locomotor stimulation induced in mice by combined tripelennamine and morphine. Further research should investigate whether glucose is also able to attenuate the effects of combined antihistaminics and opiates in other behavioral tests. Besides morphine-induced hyperactivity, in fact, other effects of the opiates - that is, the antinociceptive action-may be reduced by glucose (Lux et al., 1988; Simon \& Dewey, 1981) and enhanced by antihistaminic drugs (Bluhm, Evans, \& Zsigmond, 1983; Sun, Hui, \& Hanig, 1985; Tagashira, Kachur, Carter, \& Dewey, 1984; Yeh, 1986). But it might certainly be of great interest to ascertain the action of glucose on the euphoric effects produced by antihistaminic-opiate combinations in humans.

\section{REFERENCES}

Bluhm, R. E., Evans, M. A., \& Zsigmond, E. K. (1983). Analgesic potentiation and the distribution of morphine in the presence of tripelennamine in mice. Life Sciences, 33(Suppl. I), 673-676.

Brase, D. A., Han, Y.-H., \& Dewey, W. L. (1987). Effects of glucose and diabetes on binding of naloxone and dihydromorphine to opiate receptors in mouse brain. Diabetes, 36, 1173-1177.

Douglas, W. W. (1985). Histamine and 5-hydroxytryptamine (serotonin) and their antagonists. In A. Goodman Gilman, L. S. Goodman, T. W. Rall, \& F. Murad (Eds.), The pharmacological basis of therapeutics (pp. 605-638). New York: Macmillan.

JASINSKi, D. R., Johnson, R. E., \& HeNniNGField, J. E. (1984). Abuse liability assessment in human subjects. Trends in Pharmacological Sciences, 5, 196-200.

Khawaja, X. Z., \& Green, I. C. (1992). Studies on the effects of glucose in vitro and of the glycaemic state in vivo on the binding characteristics of mu, delta and kappa opiate receptors in mouse brain. Life Sciences, 50, 1273-1281.

Kopf, S. R., \& BaRATTI, C. M. (1994). Memory-improving actions of glucose: Involvement of a central cholinergic muscarinic mechanism. Behavioral \& Neural Biology, 62, 237-243.

KoPF, S. R., \& BaRATTI, C. M. (1996). Effects of posttraining administration of glucose on retention of a habituation response in mice: Participation of a central cholinergic mechanism. Neurobiology of Learning \& Memory, 65, 253-260.

Lahmeyer, H. V., \& Steingold R. G. (1980). Pentazocine and tripelennamine: A drug abuse epidemic. International Journal of the Addictions, 15, 1219-1232.

Leza, J. C., Lizasoain, I., \& LoREnzo, P. (1991). Effects of antihistaminics on locomotor activity in mice. Comparison with opiate and amphetamine-induced hyperactivity. General Pharmacology, 22, 293-296.

Lux, F., Brase, D. A., \& Dewey, W. L. (1988). Antagonism of antinociception in mice by glucose and fructose: Comparison of subcutaneous and intrathecal morphine. European Journal of Pharmacology, $146,337-340$

Pavone, F., Capone, F., Battaglia, M., \& Sansone, M. (1998). Shuttlebox avoidance learning in mice: Improvement by combined glucose and tacrine. Neurobiology of Learning \& Memory, 69, 204-210.

Ragozzino, M. E., Parker, M. E., \& Gold, P. E. (1992). Spontaneous alternation and inhibitory avoidance impairments with morphine injections into the medial septum. Attenuation by glucose administration. Brain Research, 597, 241-249.

Ragozzino, M. E., Unick, K. E., \& Gold, P. E. (1996). Hippocampal acetylcholine release during memory testing in rats: Augmentation by glucose. Proceedings of the National Academy of Sciences, 93, 4693-4698.

San-Martin-Clark, O., Cuellar, B., Leza, J. C., Lizasoain, I., \& LORENZO, P. (1996). Effects of trepelennamine on brain monamine turnover in morphine dependent and abstinent mice. Psychopharmacology, 123, 297-302.

Sansone, M., Castellano, C., \& D'amato, F. R. (1986). Enhancement of morphine-induced hyperactivity by antihistaminic drugs in mice. Archives Internationales de Pharmacodynamie et de Therapie, 284, 239-245

Sansone, M., D'Udine, B., Renzi, P., \& Vetulani, J. (1987). Antihistaminics enhance morphine-, but not amphetamine- and scopolamineinduced hyperactivity in mice. Psychopharmacology, 93, 155-157.

Shook, J. E., Kachur, J. F., Brase, D. A., \& Dewey, W. L. (1986). 
Morphine dependence and diabetes. II. Alterations of normorphine potency in the guinea pig ileum and mouse vas deferens and of ileal morphine dependence by changes in glucose concentration. Journal of Pharmacology \& Experimental Therapeutics, 218, 318-323.

Showalter, C. V. (1980). T's and blues: Abuse of pentazocine and tripelennamine. Journal of the American Medical Association, 244, 1224-1225.

Simon, G. S., \& DeWEy, W. L. (1981). Narcotics and diabetes: I. The effects of streptozotocin-induced diabetes on the antinociceptive potency of morphine. Journal of Pharmacology \& Experimental Therapeutics, 237, 848-852.

Stone, W. S., CotTrill, K. L., \& Gold, P. E. (1987). Glucose and epinephrine attenuation of scopolamine-induced increases in locomotor activity in mice. Neuroscience Research Communications, 1, 105-111.

Stone, W. S., Cottrill, K. L., Walker, D. L., \& Gold, P. E. (1988). Blood glucose and brain function: Interactions with CNS cholinergic systems. Behavioral \& Neural Biology, 50, 325-334

Stone, W. S., Croul, C. E., \& Gold, P. E. (1988). Attenuation of scopolamine-induced amnesia in mice. Psychopharmacology, 96, 417-420.

Stone, W. S., Rudd, R, J., \& Gold, P. E. (1990). Glucose and physostigmine effects on morphine- and amphetamine-induced increases in locomotor activity in mice. Behaviomal \& Neural Biology, 54, 146-155.
Stone, W. S., Walser, B., Gold, S. D., \& Gold, P. E. (1991). Scopolamine and morphine-induced impairments of spontaneous alternation performance in mice: Reversal with glucose and with cholinergic and adrenergic agonists. Behavioral Neuroscience, 105, 264-271.

Sun, C. L. J., Hui, F. W., \& HaNig, J. P. (1985). Effect of H1 blockers alone and in combination with morphine to produce antinociception in mice. Neuropharmacology, 24, 1-4.

Suzuki, T., Mori, T., Tsuji, M., Misawa, M., \& Onodera, K. (1997) Generalization of D-, L- and DL-chlorpheniramine and zolantidine to the discriminative stimulus effects of cocaine and methamphetamine. Behavioural Pharmacology, 8, 718-724.

Tagashira, E., Kachur, J. F., Carter, W. H., \& Dewey, W. L. (1984). Potentiation of narcotic-induced antinociception by tripelennamine in morphine-tolerant and drug-naive mice. Journal of Pharmacology \& Experimental Therapeutics, 229, 214-217.

YEH, S. Y. (1986). The effect of antihistaminic drugs on pentazocine antinociception in the rat. Pharmacology, Biochemistry \& Behavior, $\mathbf{2 4}, 925-930$

(Manuscript received May 22, 1998; revision accepted for publication July 16,1998 .)

\section{Nominations for the Editorship of Psychobiology}

Nominations are solicited for the editorship of Psychobiology. The term of the present editor, Raymond Kesner, expires at the end of 2000. The new editor will begin an official 4-or 5-year term on January 1, 2001, and will begin to receive manuscripts early in April 2000. The Publications Committee of the Psychonomic Society expects to appoint the new editor by December 1999.

Nominations (including self-nominations) should be submitted by July 1, 1999, to:

Michael I. Posner

Chair, Psychobiology Search Committee

Department of Psychiatry, Box 171

Cornell Medical College

525 E. 68th St.

New York, NY 10021 